\title{
Estrogen receptor $\beta$ expression in vascular neoplasia: an analysis of 53 benign and malignant cases
}

\author{
Andrea T Deyrup ${ }^{1}$, Maria Tretiakova ${ }^{2}$, Andrey Khramtsov² and Anthony G Montag² \\ ${ }^{1}$ Department of Pathology and Laboratory Medicine, Emory University School of Medicine, Atlanta, GA, USA \\ and ${ }^{2}$ Department of Pathology, The University of Chicago, Chicago, IL, USA
}

\begin{abstract}
The importance of estrogen in vascular neoplasia is suggested by a predilection for women and a tendency for rapid growth during pregnancy. Although early experiments using radioligand assays demonstrated estrogen receptor (ER) expression, these findings were not confirmed by subsequent immunohistochemical studies which were performed with antibodies raised against ER $\alpha$. A newly discovered estrogen receptor subtype, ER $\beta$, has not been previously characterized in vascular lesions. In order to verify the expression of estrogen receptors in vascular neoplasms as well as to clarify the inconsistency between radioligand and early immunohistochemical studies, we examined a series of 53 benign and malignant vascular neoplasms for ER $\beta$ expression. All of the subtypes of vascular neoplasia examined had nuclear expression of ER $\beta$. The majority of cases $(94 \%)$ displayed $2+$ to $3+$ staining. The discrepancy between radioligand studies and previous immunohistochemical studies is attributable to the use of antibodies raised against ER $\alpha$, which is not expressed in vascular lesions, and not ER $\beta$, which is broadly expressed in both benign and malignant vascular neoplasms. Although ER $\beta$ may be of limited diagnostic use in vascular neoplasia due to its broad expression, the potential exists for a therapeutic approach using ER agonists.
\end{abstract}

Modern Pathology (2004) 17, 1372-1377, advance online publication, 2 July 2004; doi:10.1038/modpathol.3800201

Keywords: vascular; estrogen receptor; radioligand; immunohistochemical; estrogen receptor beta

The role of estrogen in vascular neoplasia has long been suspected due to the observation that vascular neoplasms tend to grow rapidly during pregnancy and in adolescence. ${ }^{1}$ These clinical observations were initially substantiated by early experiments in the 1980s using radioligand assays, which confirmed the presence of the estrogen receptor (ER) in vascular tumors; $;^{2,3}$ however, with the advent of immunohistochemical techniques, subsequent studies performed in the 1990s with antibodies raised against the ER refuted these earlier data and it appeared that the newer technology had exposed the limitations of the older biochemical assays. ${ }^{4-7}$ Recently, an additional ER subtype, estrogen receptor beta $(\mathrm{ER} \beta),{ }^{8}$ was identified and the previous ER against which the original antibodies were raised was renamed estrogen receptor alpha (ER $\alpha)$. Although ER $\alpha$ has been assessed immunohisto-

Correspondence: Dr AG Montag, MD, Department of Pathology, MC6101, University of Chicago, 5841 S. Maryland Avenue, Chicago, IL 60637, USA.

E-mail: amontag@mcis.bsd.uchicago.edu

Received 22 January 2004; revised and accepted 6 April 2004; published online 2 July 2004 chemically in vascular neoplasms and found to be absent, ER $\beta$ has not been previously characterized in these entities. In order to verify the expression of ER in vascular tumors as well as to clarify the inconsistency between radioligand and early immunohistochemical studies, we examined a series of 53 benign and malignant vascular neoplasms for ER $\beta$ expression.

\section{Materials and methods}

In all, 22 cases of angiosarcoma, three cases of Kaposi sarcoma, one case of epithelioid hemangioendothelioma, two cases of spindle-cell hemangioma, four cases of infantile hemangioendothelioma, 13 cases of hemangioma, seven cases of lymphangioma and one case of papillary endothelial hyperplasia were identified and retrieved from the paraffin archives of the University of Chicago. Formalin-fixed paraffin-embedded specimens were cut into $4-\mu \mathrm{m}$ sections and mounted on positively charged slides. Sections were deparaffinized, rehydrated, then washed in Tris-buffered saline (TBS) and subjected to heat epitope retrieval 
in a microwave. Slides were then incubated in $1 \%$ hydrogen peroxide in methanol for $5 \mathrm{~min}$ to block endogenous peroxidase activity, followed by incubation for $20 \mathrm{~min}$ in a protein-blocking solution to reduce nonspecific antibody binding. The primary anti-human polyclonal antibody (Biogenex, San Ramon, CA, USA, 1:50) was applied for $1 \mathrm{~h}$ at room temperature. Slides were then incubated for $30 \mathrm{~min}$ at room temperature with anti-mouse or anti-rabbit IgG conjugated to a horseradish peroxidase (HRP)labeled polymer (DAKO Envision ${ }^{\text {TM }}+$ System, DAKO Corp., Carpinteria, CA, USA), treated for 5 minutes with 3-3'-diaminobenzidine (DAB) chromogen, counterstained with hematoxylin, and coverslipped. Negative controls received a nonimmune polyclonal rabbit antiserum or monoclonal mouse antibody as appropriate.

Slides were evaluated for strong nuclear staining and scored as $0,1+(<25 \%), 2+(25-50 \%)$, or $3+$ ( $>50 \%$ ) by two pathologists (ATD and AGM). Ovarian follicles or granulosa cell tumors served as positive controls for $\operatorname{ER} \beta$.

\section{Results}

All of the subtypes of vascular neoplasia examined displayed nuclear expression of ER $\beta$ (Table 1, Figure 1). The majority of cases (93\%) displayed $2+$ to $3+$ nuclear staining intensity. There was no significant difference between benign and malignant lesions. Specifically, staining intensity, percentage of tumor stained and pattern of expression were similar in both sets of tumors. Only one case of angiosarcoma was negative, with all others having $2+$ to $3+$ staining intensity. Normal endothelium (Figure 2) and the proliferating endothelium of papillary endothelial hyperplasia were also strongly positive for $\mathrm{ER} \beta$.

The cases included approximately equal numbers of male subjects and (24 M:29 F) and there was no significant difference in the presence or degree of ER $\beta$ expression across genders (Table 2).

\section{Discussion}

The ER and other steroid hormone receptors are members of the nuclear receptor superfamily of ligand-activated transcription factors. ${ }^{9}$ Following ligand binding, the ER undergoes dimerization, complexes with coregulatory molecules and binds to the promoter area of targeted genes. ${ }^{10}$ Regulation of ER function depends on the relative agonistic and antagonistic properties of the ligands and the combination of repressing and stimulating co-regulatory molecules present in the cell. In the 1970s, antibodies to the ER were produced with subsequent development of paraffin-stable monoclonal antibodies in the 1990s. In 1996, a second ER protein was cloned from rat prostate and ovary ${ }^{8}$ and was consequently identified in humans. ${ }^{11}$ The originally defined ER has since been designated ER $\alpha$, while the more recently discovered receptor has been designated $\mathrm{ER} \beta$. $\mathrm{ER} \beta$ displays significant homology with $\mathrm{ER} \alpha$ in the transcription activating and ligand binding domains, although the domains involved in the binding of coactivators and corepressors show substantially less homology. ER $\beta$ has a number of isoforms as a result of differential splicing, which appear to have some tissue specificity. ${ }^{12,13}$

$\mathrm{ER} \alpha$ and $\mathrm{ER} \beta$ have different tissue distributions, although with considerable overlap in breast and other organs. ER $\beta$ is present in most CNS cells, prostate, ovary, connective tissues of many organs and lymphocytes, ${ }^{14,15}$ decreasing its diagnostic utility. Modulation of estrogen binding depends on the variable distribution of receptor types and subtypes, their varying avidity for ligands, and a constellation of coactivators and corepressors. For example, U2OS osteosarcoma cell lines transfected with inducible $\mathrm{ER} \alpha$ or $\operatorname{ER} \beta$ and studied with an Affymetrix GeneChip ${ }^{\text {tm }}$ array were found to have fewer than a quarter of their estraidiol-, raloxifeneand tamoxifen-regulated genes in common. ${ }^{16}$ The differential function of the two ER genes is illustrated in the placenta, where ER $\beta$ is expressed in syncytiotrophoblast, ER $\alpha$ in cytotrophoblast and where they appear to promote proliferation and differentiation, respectively. ${ }^{17}$

Clinical measurement of ER protein has been a routine practice since the 1970s; however, as biomedical science has advanced, the methodology has changed over the years, with varying results. Early assays were based on ligand-binding techniques, which involved either radioligand binding or

Table 1 ER $\beta$ expression in vascular neoplasms

\begin{tabular}{|c|c|c|c|c|}
\hline Diagnosis (53) & 0 & $1+$ & $2+$ & $3+$ \\
\hline Angiosarcoma (22) & $1 / 22(5 \%)$ & 0 & $4 / 22(18 \%)$ & $17 / 22(77 \%)$ \\
\hline Kaposi sarcoma (3) & 0 & 0 & $1 / 3(33 \%)$ & $2 / 3(67 \%)$ \\
\hline Epithelioid hemangioendothelioma (1) & 0 & 0 & 0 & $1 / 1(100 \%)$ \\
\hline Spindle-cell hemangioma (2) & 0 & 0 & 0 & $2 / 2(100 \%)$ \\
\hline Infantile hemangioendothelioma (4) & 0 & $2 / 4(50 \%)$ & 0 & $2 / 4(50 \%)$ \\
\hline Hemangioma (13) & 0 & $1 / 13(8 \%)$ & 2/13 (15\%) & 10/13 (77\%) \\
\hline Lymphangioma (7) & 0 & 0 & 0 & $7 / 7(100 \%)$ \\
\hline \multirow[t]{2}{*}{ Papillary endothelial hyperplasia (1) } & 0 & 0 & 0 & $1 / 1(100 \%)$ \\
\hline & $1 / 53(2 \%)$ & $3 / 53(5 \%)$ & $7 / 53(13 \%)$ & $42 / 53(80 \%)$ \\
\hline
\end{tabular}



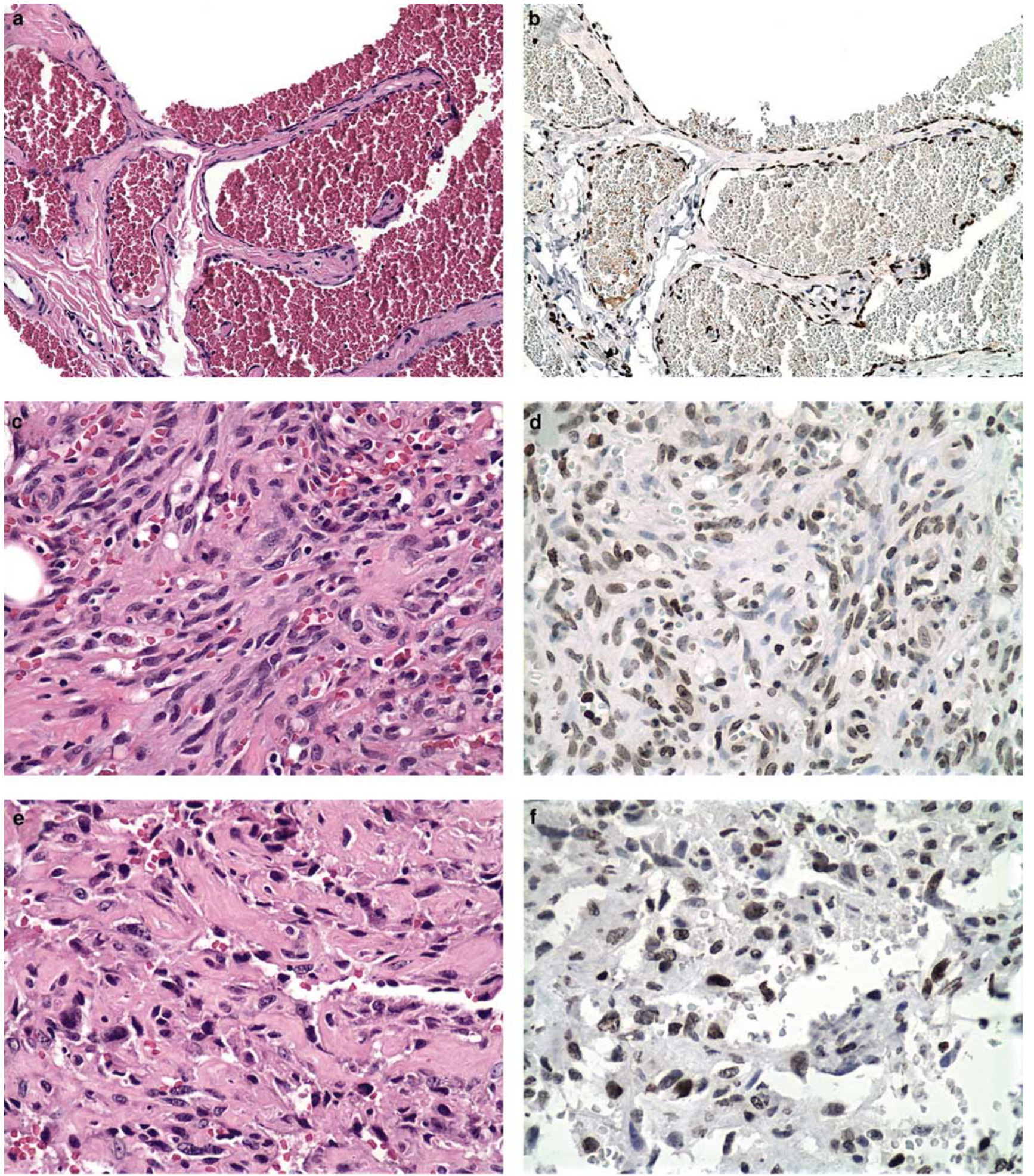

Figure 1 ER $\beta$ expression in (a, b) capillary hemangioma; (c, d) Kaposi sarcoma; (e, f) angiosarcoma.

fluorescent hormone binding. In the 1980s, these methods were supplanted by monoclonal antibodybased techniques, such as immunohistochemistry and immunoenzyme assays. ${ }^{18,19}$ Although initial comparisons of the methods in breast carcinoma found a good correlation between the two techniques, no systematic comparison was made in mesenchymal lesions. ${ }^{20}$ Since ligand-binding assays assess binding of a radiolabeled or fluoresceinlabeled ligand, this technique measures both ER $\alpha$ 


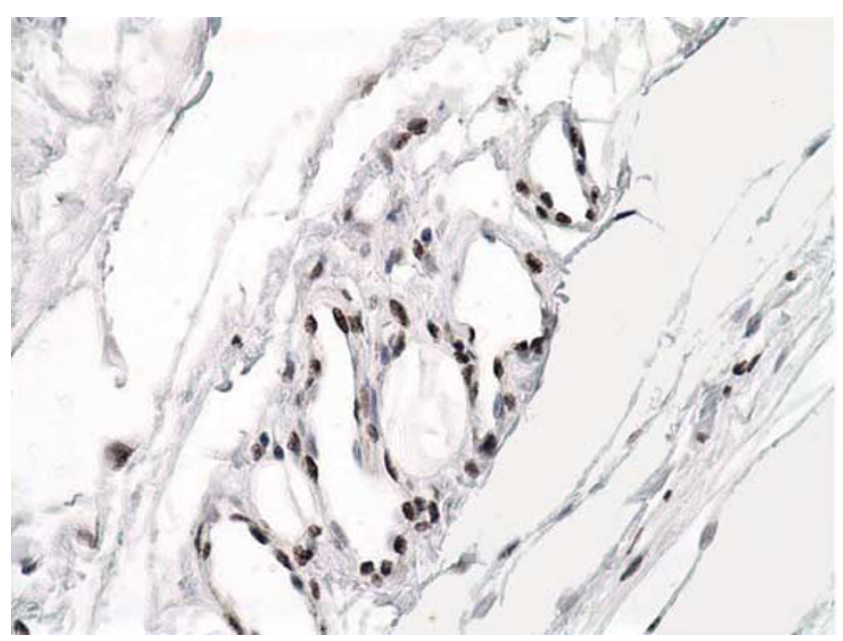

Figure 2 ER $\beta$ expression in normal capillaries.

Table 2 ER $\beta$ expression as a function of gender

\begin{tabular}{lllll}
\hline Gender & 0 & $1+$ & $2+$ & $3+$ \\
\hline Male (24) & 0 & 2 & 4 & 18 \\
Female (29) & 1 & 1 & 4 & 23 \\
\hline
\end{tabular}

and ER $\beta$. Today, virtually all ER determinations are performed with an antibody-based method, typically using a monoclonal antibody against the ER $\alpha$ protein which, due to the specificity of the antibody, only detects ER $\alpha$. Therefore, any tissue expressing only $\operatorname{ER} \beta$ will result in a false negative, accounting for the historical discrepancy in the literature regarding ER in vascular tumors.
The influence of hormones in vascular neoplasia has long been suspected due to an increased incidence in women and a tendency for rapid growth during pregnancy. Ligand binding assays of steroid hormone receptors in vascular tumors gave variable results, with only two studies reporting the presence of ER. (Table 3). Subsequently, Kumagami $^{21}$ used antibodies to steroid hormones to detect bound hormone in tissue sections and discovered evidence of bound estradiol and progesterone in $5 / 5$, testosterone in $2 / 5$, and dihydrotestosterone in $3 / 5$ cases. Later, immunohistochemical studies were uniformly negative for ER, including a large series by Hwang et $a l^{22}$ and Liang et al. ${ }^{23}$ These studies employed commercially available anti-ER $\alpha$ antibodies and, consequently, would be expected to fail to detect $\operatorname{ER} \beta$. The antibody against $\operatorname{ER} \beta$ used in the current study was raised against a peptide sequence from the carboxy terminus of $\operatorname{ER} \beta$, a region of the protein that lacks homology to the corresponding area of ER $\alpha .{ }^{24}$ Lack of cross reactivity with ER $\alpha$ was confirmed via Western blot (Biogenex, personal communication). The data described here clarify the earlier errors promoted through the use of antibodies raised against ER $\alpha$, and establish that $\mathrm{ER} \beta$ is strongly expressed in vascular neoplasms.

Although the spectrum of mesenchymal neoplasms remains to be evaluated, ER $\beta$ expression has been characterized in a number of adenocarcinomas including those of the breast, ${ }^{25}$ ovary, ${ }^{26-28}$ endometrium, ${ }^{29}$ esophagus, ${ }^{30}$ stomach $^{31}$ and colon. ${ }^{31,32}$ Interestingly, in breast, ${ }^{25}$ ovary ${ }^{25-28}$ and endometrium,,$^{29}$ malignancy is associated with loss of ER $\beta$ expression while in adenocarcinoma of the esophagus $^{30}$ increased expression is seen. One study has shown decreased ER $\beta$ expression in colonic adenocarcinoma $^{31}$ while another study ${ }^{32}$ suggests that, as

Table 3 ER expression in vascular neoplasia from historical literature

\begin{tabular}{|c|c|c|c|c|c|}
\hline Author & Year & Tumor type & Site & Cases positive/total cases & Methodology \\
\hline Chaudhuri et $a l^{41}$ & 1980 & Angiosarcoma & Soft tissue & $3 / 5$ & Ligand binding \\
\hline Chaudhuri et $a l^{42}$ & 1981 & Angiosarcoma & Soft tissue & $2 / 10$ & Ligand binding \\
\hline Bracaglia et $a l^{43}$ & 1982 & Angiosarcoma & Breast & $0 / 1$ & Ligand binding \\
\hline Brentani et $a l^{2}$ & 1983 & Angiosarcoma & Breast & $2 / 2$ & Ligand binding \\
\hline Sasaki et $a l^{3}$ & 1984 & Strawberry hemangioma & Skin & $9 / 9$ & Ligand binding \\
\hline Baker et al ${ }^{1}$ & 1985 & Hemangioma, cavernous & Skin & $0 / 1$ & Ligand binding \\
\hline Weiss and Enzinger ${ }^{44}$ & 1986 & Spindle cell hemangioendothelioma & Soft tissue & $0 / 2$ & Ligand binding \\
\hline Ohori et $a l^{4}$ & 1991 & Epithelioid hemangioendothelioma & Lung & $0 / 5$ & IHC \\
\hline Anderson et $a l^{5}$ & 1991 & Pseudoangiomatous hyperplasia & Breast & $0 / 5$ & IHC \\
\hline Nichols et $a l^{6}$ & 1992 & Lobular capillary hemangioma & Soft tissue & $0 / 21$ & IHC \\
\hline Bollinger et $a l^{7}$ & 1994 & Epithelioid hemangioendothelioma & Multifocal & $0 / 1$ & IHC \\
\hline Saegusa et $a l^{45}$ & 1995 & Cavernous hemangioma & Liver & $0 / 4$ & Ligand binding \\
\hline Powell et $a l^{46}$ & 1995 & Pseudoangiomatous hyperplasia & Breast & $4 / 14$ & IHC \\
\hline Singh et $a l^{47}$ & 1996 & Angiosarcoma & Breast & $0 / 1$ & IHC \\
\hline Rivasi et $a l^{48}$ & 1996 & Hemangioma & Ovary & $0 / 3$ & IHC \\
\hline Lamovec and Bracho ${ }^{49}$ & 1996 & Epithelioid hemangioma & Bone & $0 / 3$ & IHC \\
\hline Schammel and Tarassoli ${ }^{50}$ & 1998 & Angiosarcoma & Uterus & $0 / 4$ & IHC \\
\hline Jurkovic et $a l^{51}$ & 1999 & Hemangioma & Ovary & $0 / 1$ & IHC \\
\hline Schwartz et $a l^{52}$ & 2000 & Hemangioma & Bone & $0 / 1$ & IHC \\
\hline DiTomaso et $a l^{53}$ & 2000 & Cavernous hemangioma & Skin & $0 / 10$ & IHC \\
\hline Miliaras et $a l^{54}$ & 2001 & Hemangioma, capillary & Ovary & $1 / 1$ & IHC \\
\hline
\end{tabular}


is seen in gastric adenocarcinoma, ${ }^{30}$ there is no significant difference between normal and dysplastic mucosa. The situation is complicated by the recent discovery of additional splice variants and isoforms of $\mathrm{ER} \beta$ in normal tissue $\mathrm{e}^{33-35}$ as well as evidence that the interaction of $\operatorname{ER} \alpha$ and $\operatorname{ER} \beta$ levels may play a role in carcinogenesis. ${ }^{28}$

The demonstration of ER $\beta$ in vascular neoplasms suggests a role for estrogen antagonists in the therapy of the most aggressive vascular tumors: angiosarcomas. Although rare, angiosarcomas have a uniformly poor prognosis, which correlates with tumor site and size. ${ }^{36,37}$ Moreover, perhaps due to their association with the systemic vasculature, angiosarcomas metastasize widely and often present initially with multifocal disease, rendering them particularly refractory to surgical therapy. A new generation of antiestrogenic compounds and selective ER modulators (SERM) are in development, some of which preferentially target ER $\beta .^{38-40}$ As yet, none of these SERM has been tested in angiosarcomas and it remains uncertain whether the effect on normal endothelial cells would preclude systemic therapy. Nonetheless, further study is warranted.

We have demonstrated that, despite previous immunohistochemical evidence to the contrary, a broad range of benign and malignant vascular neoplasms as well as normal blood vessels express ER, specifically ER $\beta$. Furthermore, we have showed that the previous inconsistencies in the ER status of vascular neoplasms - and perhaps other entities as well-are attributable to the unexpected existence of a second ER which remains to be fully classified. It is perhaps worth contemplating the existence of a third ER, as yet undetected by our more modern methods but fully present to the biochemists of before.

\section{References}

1 Baker ER, Manders E, Whitney CW. Growth of cavernous hemangioma with puberty. Clin Pediatr (Phila) 1985;24:596-598.

2 Brentani MM, Pacheco MM, Oshima CT, et al. Steroid receptors in breast angiosarcoma. Cancer 1983;51: 2105-2111

3 Sasaki GH, Pang CY, Wittliff JL. Pathogenesis and treatment of infant skin strawberry hemangiomas: clinical and in vitro studies of hormonal effects. Plast Reconstr Surg 1984;73:359-370.

4 Ohori NP YS, Sonmez-Alpan E, Colby TV. Estrogen and progesterone receptors in lymphangioleiomyomatosis, epithelioid hemangioendothelioma, and sclerosing hemangioma of the lung. Am J Clin Pathol 1991;96:529-535.

5 Anderson C, Ricci Jr A, Pedersen CA, et al. Immunocytochemical analysis of estrogen and progesterone receptors in benign stromal lesions of the breast. Evidence for hormonal etiology in pseudoangiomatous hyperplasia of mammary stroma. Am J Surg Pathol 1991;15:145-149.
6 Nichols GE, Gaffey MJ, Mills SE, et al. Lobular capillary hemangioma. An immunohistochemical study including steroid hormone receptor status. Am J Clin Pathol 1992;97:770-775.

7 Bollinger BK, Laskin WB, Knight CB. Epitheliod hemangioendothelioma with multiple site involvement. Literature review and observations. Cancer 1994;73:610-615.

8 Kuiper GG, Enmark E, Pelto-Huikko M, et al. Cloning of a novel receptor expressed in rat prostate and ovary. Proc Natl Acad Sci 1996;93:5925-5930.

9 Robinson-Rechavi M, Escriva Garcia H, Laudet V. The nuclear receptor superfamily. J Cell Sci. 2003;116: 585-586.

10 Osborne CK, Schiff R, Fuqua SA, et al. Estrogen receptor: current understanding of its activation and modulation. Clin Cancer Res 2001;7:4338-4342.

11 Mosselman S, Polman J, Dijkema R. ER beta: identification and characterization of a novel estrogen receptor. FEBS Lett 1996;392:49-53.

12 Lewandowski S, Kalita K, Kaczmarek L. Estrogen receptor beta: Potential functional significance of a variety of mRNA isoforms. FEBS Lett 2002;524:1-5.

13 Pettersson K, Gustafsson JA. Role of estrogen receptor beta in estrogen action. Ann Rev Physiol 2001;63: 165-192.

14 Taylor AH, Al-Azzawi F. Immunolocalization of oestrogen receptor beta in human tissues. J Mol Endocrinol 2000;24:145-155.

15 Chu S, Mamers P, Burger HG, et al. Estrogen receptor isoform gene expression in ovarian stromal and epithelial tumors. J Clin Endocrinol Metab 2000; 85:1200-1205.

16 Kian Tee M, Rogtasky I, Tzagarakis-Foster C, et al. Estradiol and selective estrogen receptor modulators differentially regulate target genes with estrogen receptors $\alpha$ and $\beta$. Mol Biol Cell Epub 2004;15: 1262-1272.

17 Bukovsky A, Caudle MR, Cekanova M, et al. Placental expression of estrogen receptor beta and its hormone binding variant-comparison with estrogen receptor alpha and a role for estrogen receptors in asymmetric division and differentiation of estrogen-dependent cells. Reprod Biol Endocrinol 2003;1:36.

18 Vonderhaar V, Mueller GC. Binding of estrogen receptor to estriadiol immobilized on insoluble resins. Biochim Biophys Acta 1969;176: 626-631.

19 McCarty Jr KS, McCarty Sr KS. Histochemical approaches to steroid receptor analyses. Semin Diagn Pathol 1984;1:297-308.

20 King WJ, DeSombre ER, Jensen EV, et al. Comparison of immunocytochemical and steroid-binding assays for estrogen receptor in human breast tumors. Cancer Res 1985;45:293-304.

21 Kumagami H. Sex hormones in juvenile nasopharyngeal angiofibroma tissue. Auris Nasus Larynx 1993;20: 131-135.

22 Hwang HC, Mills SE, Patterson K, et al. Expression of androgen receptors in nasopharyngeal angiofibroma: an immunohistochemical study of 24 cases. Mod Pathol 1998;11:1122-1126.

23 Liang J, Yi Z, Lianq P. The nature of juvenile nasopharyngeal angiofibroma. Otolaryngol Head Neck Surg 2000;123:475-481.

24 Pavao M, Traish AM. Estrogen receptor antibodies: specificity and utility in detection, localization and 
analyses of estrogen receptor alpha and beta. Steroids 2001;66:1-16.

25 Shaaban AM, O’Neill PA, Davies MP, et al. Declining estrogen receptor-beta expression defines malignant progression of human breast neoplasia. Am J Surg Pathol 2003;27:1502-1512.

26 Rutherford T, Brown WD, Sapi E, et al. Absence of estrogen receptor-beta expression in metastatic ovarian cancer. Obstet Gynecol 2000;96:417-422.

27 Fujimoto J, Hirose R, Sakaguchi H, et al. Clinical significance of expression of estrogen receptor alpha and beta mRNAs in ovarian cancers. Oncology 2000;58:334-341.

28 Sakaguchi H, Fujimoto J, Aoki I, et al. Expression of oestrogen receptor $\alpha$ and $\beta$ in uterine endometrial and ovarian cancers. Eur J Cancer 2002;38(Suppl 6): S74-S75.

29 Akgun H, Lechago J, Younes M. Estrogen receptor-beta is expressed in Barrett's metaplasia and associated adenocarcinoma of the esophagus. Anticancer Res 2002;22:1459-1461.

30 Matsuyama S, Ohkura Y, Eguchi H, et al. Estrogen receptor beta is expressed in human stomach adenocarcinoma. J Cancer Res Clin Oncol. 2002;128: 319-324.

31 Xie L-Q, Yu J-P, Luo H-S. Expression of estrogen receptor $\beta$ in human colorectal cancer. World J Gastroenterol 2004;10:214-217.

32 Konstantinopoulos PA, Kominea A, Vandoros G, et al. Oestrogen receptor beta $(\mathrm{ER} \beta)$ is abundantly expressed in normal colonic mucosa, but declines in colonic adenocarcinoma paralleling the tumour's dedifferentiation. Eur J Cancer 2003;39:1251-1258.

33 Poola I, Abraham J, Baldwin K. Identification of ten exon deleted $\operatorname{ER} \beta$ mRNAs in human ovary, breast, uterus and bone tissues: alternate splicing pattern of estrogen receptor $\beta$ mRNA is distinct from that of estrogen receptor $\alpha$. FEBS Lett 2002;516: 133-138.

$34 \mathrm{Lu} \mathrm{B}$, Leygue E, Dotzlaw H, et al. Estrogen receptor- $\beta$ mRNA variants in human and murine tissues. Mol Cell Endocrinol 1998;138:199-203.

$35 \mathrm{Lu} \mathrm{B}$, Leygue E, Dotzlaw $\mathrm{H}$, et al. Functional characteristics of a novel murine estrogen receptor- $\beta$ isoform, estrogen receptor- $\beta 2$. J Mol Endocrinol 2000; 25:229-242.

36 Marchal C, Weber B, de Lafontan B, et al. Nine breast angiosarcomas after conservative treatment for breast carcinoma: a survey from French comprehensive Cancer Centers. Int J Radiat Oncol Biol Phys 1999; 44:113-119.

37 Mark RJ, Tran LM, Sercarz J, et al. Angiosarcoma of the head and neck. The UCLA experience 1955 through 1990. Arch Otolaryngol Head Neck Surg 1993;119: 973-978.

38 Harris HA, Albert LM, Leathurby Y, et al. Evaluation of an estrogen receptor-beta agonist in animal models of human disease. Endocrinology 2003;144:4241-4249.
39 Meyers MJ, Sun J, Carlson KE, et al. Estrogen receptorbeta potency-selective ligands: structure-activity relationship studies of diarylpropionitriles and their acetylene and polar analogues. J Med Chem 2001;44: 4230-4251.

40 Henke BR, Consler TG, Go N, et al. A new series of estrogen receptor modulators that display selectivity for estrogen receptor beta. J Med Chem 2002;45: 5492-5505.

41 Chaudhuri PK, Walker MJ, Beattie CW, et al. Presence of steroid receptors in human soft tissue sarcomas of diverse histological origin. Cancer Res 1980;40: 861-865.

42 Chaudhuri PK, Walker MJ, Beattie CW, et al. Distribution of steroid hormone receptors in human soft tissue sarcomas. Surgery 1981;90:149-153.

43 Bracaglia R, Seccia A, Farallo E, et al. Steroid hormone receptors in female breast angiosarcoma. Ann Plast Surg 1982;9:61-64.

44 Weiss SW, Enzinger FM. Spindle cell hemangioendothelioma. A low grade angiosarcoma resembling a cavernous hemangioma and Kaposi's sarcoma. Am J Surg Pathol 1986;10:521-530.

45 Saegusa T, Ito K, Oba N, et al. Enlargement of multiple cavernous hemangioma of the liver in association with pregnancy. Intern Med 1995;34:207-211.

46 Powell CM, Cranor ML, Rosen PP. Pseudoangiomatous stromal hyperplasia (PASH). A stromal tumor with myofibroblastic differentiation. Am J Surg Pathol 1995;19:270-277.

47 Singh Y, Inoue K, Kawanishi $\mathrm{H}$, et al. Angiosarcoma of the breast: Immunohistochemical demonstration of steroid receptors and literature review. Breast Cancer 1996;3:125-129.

48 Rivasi F, Philippe E, Walter P, et al. Ovarian angioma. Report of 3 asymptomatic cases. Ann Pathol 1996;16: 439-441.

49 Lamovec J, Bracko M. Epithelioid hemangioma of small tubular bones: a report of three cases, two of them associated with pregnancy. Mod Pathol 1996; 9:821-827.

50 Schammel DP, Tavassoli FA. Uterine angiosarcomas: a morphologic and immunohistochemical study of four cases. Am J Surg Pathol 1998;22:246-250.

51 Jurkovic I, Dudrikova, Boor A. Ovarian hemangioma. Cesk Patol 1999;35:133-135.

52 Schwartz TH, Hibshoosh H, Riedel CJ. Estrogen and progesterone receptor-negative T11 vertebral hemangioma presenting as a postpartum compression fracture: case report and management. Neurosurgery 2000;46:218-221.

53 Di Tommaso L, Scarpellini F, Salvi F, et al. Progesterone receptor expression in orbital cavernous hemangiomas. Virchows Arch 2000;436:284-288.

54 Miliaras D, Papaemmanouil S, Blatzas G. Ovarian capillary hemangioma and stromal luteinization: a case study with hormonal receptor evaluation. Eur J Gynaecol Oncol 2001;22:369-371. 